\title{
Gambaran Kehilangan Gigi pada Mahasiswa Tahap Profesi Dokter Gigi
}

\author{
Juliatri, Pritartha S. Anindita
}

\author{
Program Studi Pendidikan Dokter Gigi Fakultas Kedokteran Universitas Sam Ratulangi, \\ Manado, Indonesia \\ Email: juliatri31@unsrat.ac.id \\ Disubmisi: 01 Desember 2021; direvisi: 10 Desember 2021; diterima: 12 Desember 2021
}

\begin{abstract}
Tooth loss can occur due to various causes including caries and periodontal disease. Dental clerkship students are expected to have a good level of understanding of dental and oral health, therefore, they can prevent tooth loss due to dental and oral diseases such as caries or periodontal disease. This study was aimed to obtain the description of tooth loss among dental clerkship students at Program Studi Pendidikan Dokter Gigi, Faculty of Medicine, Sam Ratulangi University (PSPDG FK Unsrat) Manado. This was a descriptive study with a cross sectional design using total sampling method. Data were collected by means of questionnaires containing the identity and status of respondents with tooth loss, and were analyzed to determine the frequency and distribution of tooth loss. Out of a total of 228 students, 156 students filled in the questionnaires with a response rate of $68.4 \%$. The results showed that 103 or $66 \%$ of respondents experienced tooth loss of one or more teeth and the total number of all missing teeth were 240 teeth. Caries was the most prominent cause of tooth loss, as many as 144 teeth or $60 \%$. Of the 240 missing teeth, 202 teeth were not replaced with dentures. In conclusion, the prevalence of tooth loss among dental clerkship students at PSPDG FK Unsrat was 66\%. Caries was the most common cause of tooth loss. Most of the missing teeth were not replaced with dentures for various reasons.
\end{abstract}

Keywords: tooth loss; dental student

\begin{abstract}
Abstrak: Kehilangan gigi dapat terjadi akibat berbagai hal di antaranya karies dan penyakit periodontal. Mahasiswa tahap profesi dokter gigi diharapkan memiliki tingkat pemahaman tentang kesehatan gigi dan mulut yang baik sehingga dapat mencegah kehilangan gigi yang disebabkan oleh penyakit gigi dan mulut seperti karies atau penyakit periodontal. Penelitian ini bertujuan untuk mengetahui gambaran kehilangan gigi pada mahasiswa tahap profesi dokter gigi di Program Studi Pendidikan Dokter Gigi Fakultas Kedokteran Universitas Sam Ratulangi (PSPDG FK Unsrat) Manado. Jenis penelitian ialah deskriptif dengan desain potong lintang. Penentuan sampel dengan metode total sampling. Data dikumpulkan menggunakan kuesioner yang berisi identitas dan status kehilangan gigi responden, dan dianalisis untuk mengetahui frekuensi dan distribusi kehilangan gigi responden. Dari total 228 mahasiswa, sebanyak 156 mahasiswa mengisi kuesioner dengan response rate sebesar $68,4 \%$. Hasil penelitian menunjukkan 103 atau 66\% responden mengalami kehilangan satu atau lebih gigi dengan jumlah keseluruhan gigi yang hilang 240 gigi. Karies merupakan penyebab kehilangan gigi paling tinggi yaitu sebanyak 144 gigi atau 60\%. Dari 240 gigi yang hilang, sebanyak 202 gigi tidak dibuatkan gigi tiruan. Simpulan penelitian ini ialah prevalensi kehilangan gigi pada mahasiswa tahap profesi PSPDG FK Unsrat sebesar 66\%. Karies merupakan penyebab kehilangan gigi paling tinggi. Sebagian besar gigi yang hilang tidak dibuatkan gigi tiruan dengan berbagai alasan.
\end{abstract}

Kata kunci: kehilangan gigi; mahasiswa kedokteran gigi

\section{PENDAHULUAN}

Kehilangan gigi merupakan suatu keadaan tidak bergigi, baik sebagian ataupun keseluruhan. ${ }^{1}$ Kejadian hilangnya gigi 
dapat terjadi pada anak-anak mulai usia 6 tahun yang mengalami hilangnya gigi sulung dan kemudian digantikan oleh gigi permanen. Hilangnya gigi permanen juga dapat dialami oleh orang dewasa dan hal ini tentunya sangat tidak diinginkan. ${ }^{2}$

Hilangnya gigi dapat terjadi akibat karies, penyakit periodontal, trauma, infeksi, keganasan, ataupun perawatan endodontik yang gagal. ${ }^{3}$ Selain itu, terdapat faktorfaktor yang dapat memodifikasi penyebab ini seperti jenis kelamin ${ }^{3}$, tingkat pendidikan, usia ${ }^{3,4}$, faktor sosial ekonomi, akses ke perawatan gigi, rasio dokter gigi/ penduduk. ${ }^{4}$

Keadaan hilangnya gigi dapat memengaruhi fungsi pengunyahan, berbicara, dan penampilan sehingga berdampak pada kualitas hidup seseorang. ${ }^{1}$ Kesulitan mengunyah sebagai akibat dari kehilangan gigi menyebabkan seseorang melakukan pembatasan diet dan dengan demikian menimbulkan risiko kesehatan. Pergeseran gigi yang berdekatan dan supra-erupsi gigi antagonis ke ruang edentulous dapat terjadi pada seseorang yang mengalami kehilangan gigi. Akibat lain yaitu terjadi asimetri pada wajah. ${ }^{3}$ Mengingat risiko yang ditimbulkan akibat kehilangan gigi, maka gigi tiruan sangat diperlukan untuk mengembalikan fungsi gigi asli yang hilang dan jaringan pendukungnya.

Mahasiswa tahap profesi dokter gigi dapat dikatakan memiliki tingkat pemahaman tentang kesehatan gigi dan mulut yang baik karena telah mendapatkan pengetahuan tentang ilmu kedokteran gigi selama setidaknya empat tahun pada tahap akademik hingga meraih gelar sarjana kedokteran gigi (SKG). Dalam tahap profesi dokter gigi, mahasiswa diwajibkan menyelesaikan sejumlah requirement perawatan pasien dengan berbagai kasus di bawah pengawasan dokter gigi.

Pemahaman yang baik tentang masalah gigi dan mulut dapat meningkatkan kesadaran dan perhatian terhadap kesehatan gigi. Dengan demikian, dapat mencegah kehilangan gigi yang disebabkan oleh penyakit gigi dan mulut seperti karies dan penyakit periodontal. Selain itu mahasiswa tahap profesi dokter gigi dengan tingkat pengetahuan yang baik tentang pentingnya penggantian gigi yang hilang, seharusnya memasang gigi tiruan apabila terdapat gigi yang hilang.

Dengan dasar pemikiran tersebut, penulis tertarik untuk mengetahui lebih lanjut mengenai gambaran kehilangan gigi pada mahasiswa tahap profesi dokter gigi di Program Studi Pendidikan Dokter Gigi Fakultas Kedokteran Universitas Sam Ratulangi (PSPDG FK Unsrat) Manado.

\section{METODE PENELITIAN}

Jenis penelitian ini ialah deskriptif dengan desain potong lintang. Penelitian dilakukan pada mahasiswa tahap profesi PSPDG FK Unsrat pada bulan November 2021. Populasi penelitian yakni mahasiswa tahap profesi PSPDG FK Unsrat berjumlah 228 orang. ${ }^{5}$ Pengambilan sampel menggunakan metode total sampling. Data dikumpulkan melalui kuesioner online menggunakan google form yang berisi identitas dan status kehilangan gigi responden.

Data dianalisis secara univariat dengan program SPSS untuk mengetahui frekuensi dan distribusi kehilangan gigi pada mahasiswa tahap profesi PSPDG FK Unsrat.

\section{HASIL PENELITIAN}

Dari 228 orang yang terdaftar sebagai mahasiswa tahap profesi PSPDG FK Unsrat, sebanyak 156 mahasiswa bersedia berpartisipasi dalam penelitian ini dengan mengisi kuesioner atau response rate sebesar 68,4\%. Tabel 1 memperlihatkan bahwa 103 atau $66 \%$ responden mengalami kehilangan gigi. Jenis kelamin perempuan lebih banyak kehilangan gigi dibanding laki-laki.

Setiap orang dapat saja kehilangan gigi lebih dari satu, bahkan terdapat responden yang mengalami kehilangan tujuh gigi. Tabel 2 memperlihatkan bahwa responden paling banyak mengalami kehilangan dua gigi yaitu 40 orang.

Hilangnya gigi dapat disebabkan oleh berbagai hal. Tabel 3 memperlihatkan bahwa karies merupakan penyebab kehilangan gigi paling tinggi yaitu sebanyak 144 gigi atau $60 \%$ (Tabel 3). 
Kehilangan gigi dapat memengaruhi fungsi pengunyahan, berbicara, dan penampilan sehingga berdampak pada kualitas hidup seseorang. Oleh sebab itu, gigi yang hilang harus digantikan dengan gigi tiruan. Tabel 4 memperlihatkan dari 240 gigi yang hilang, sebanyak 202 gigi tidak dibuatkan gigi tiruan dengan berbagai alasan.

Tabel 1. Prevalensi kehilangan gigi pada mahasiswa tahap profesi PSPDG FK Unsrat berdasarkan karakteristik responden

\begin{tabular}{|c|c|c|c|c|c|c|c|}
\hline \multicolumn{2}{|c|}{ Karakteristik responden } & \multicolumn{4}{|c|}{ Kehilangan gigi } & \multicolumn{2}{|c|}{ Jumlah } \\
\hline & & \multicolumn{2}{|c|}{ Ya } & \multicolumn{2}{|c|}{ Tidak } & \multirow[b]{2}{*}{$\mathrm{n}$} & \multirow[b]{2}{*}{$\%$} \\
\hline & & $\mathrm{n}$ & $\%$ & $\mathrm{n}$ & $\%$ & & \\
\hline \multirow[t]{2}{*}{ Jenis kelamin } & Laki-laki & 33 & 21,2 & 13 & 8,3 & 46 & 29,5 \\
\hline & Perempuan & 70 & 44,9 & 40 & 25.6 & 110 & 70,5 \\
\hline \multirow[t]{3}{*}{ Usia } & $\leq 25$ tahun & 16 & 10,3 & 17 & 10,9 & 33 & 21,2 \\
\hline & 26-29 tahun & 62 & 39,7 & 30 & 19,2 & 92 & 59,0 \\
\hline & $\geq 30$ tahun & 25 & 16,0 & 6 & 3,8 & 31 & 19,9 \\
\hline Total & & 103 & 66,0 & 53 & 34,0 & 156 & 100 \\
\hline
\end{tabular}

Tabel 2. Jumlah kehilangan gigi pada mahasiswa tahap profesi PSPDG FK Unsrat

\begin{tabular}{ccc}
\hline $\begin{array}{c}\text { Jumlah gigi yang hilang } \\
\text { per orang }\end{array}$ & n (orang) & $\begin{array}{c}\text { Jumlah keseluruhan gigi } \\
\text { yang hilang }\end{array}$ \\
\hline 1 & 28 & 28 \\
2 & 40 & 80 \\
3 & 17 & 51 \\
4 & 11 & 44 \\
5 & 6 & 30 \\
7 & 1 & 7 \\
Total & 103 & 240 \\
\hline
\end{tabular}

Tabel 3. Distribusi faktor penyebab kehilangan gigi pada mahasiswa tahap profesi PSPDG FK Unsrat

\begin{tabular}{lcc}
\hline Penyebab kehilangan gigi & n (gigi) & \% \\
\hline Karies & 144 & 60 \\
Keperluan perawatan ortodonsi & 62 & 25,8 \\
Impaksi & 28 & 11,7 \\
Kecelakaan & 6 & 2,5 \\
Total & 240 & 100 \\
\hline
\end{tabular}

Tabel 4. Distribusi hal-hal yang menjadi pertimbangan mahasiswa tahap profesi PSPDG FK Unsrat yang mengalami kehilangan gigi sehingga tidak menggunakan gigi tiruan

\begin{tabular}{lcc}
\hline Alasan gigi yang hilang tidak digantikan dengan gigitiruan & n (gigi) & \% \\
\hline Gigi yang diganti dengan gigi tiruan & 38 & 15,8 \\
Gigi yang hilang tidak diganti dengan gigi tiruan & 202 & 84,2 \\
Tidak ada waktu/belum sempat & 46 & 22,7 \\
Merasa tidak terganggu & 26 & 12,9 \\
Biaya pembuatan gigi tiruan mahal & 14 & 6,9 \\
Tidak perlu digantikan dengan gigi tiruan & 5 & 2,5 \\
Takut atau ragu memakai gigi tiruan & 4 & 2,0 \\
Belum terpikirkan & 17 & 8,4 \\
Karena gigi yang dicabut untuk keperluan perawatan ortodonsi & 62 & 30,7 \\
Karena gigi yang dicabut merupakan gigi impaksi & 28 & 13,9 \\
Total & 240 & 100 \\
\hline
\end{tabular}




\section{BAHASAN}

Prevalensi kehilangan gigi pada mahasiswa tahap profesi PSPDG FK Unsrat didapatkan sebesar 66\% (Tabel 1). Dari 156 responden, sebanyak 103 orang mengalami kehilangan gigi. Angka ini dapat diartikan bahwa kehilangan gigi terjadi pada lebih dari setengah mahasiswa tahap profesi PSPDG FK Unsrat. Hasil penelitian ini menunjukkan bahwa meskipun responden sebagai mahasiswa tahap profesi dokter gigi yang telah mendapatkan pengetahuan tentang ilmu kedokteran gigi, tetap tidak dapat menghindari terjadinya kehilangan gigi sehingga prevalensi kehilangan gigi pada responden cukup tinggi. Kehilangan gigi yang dialami kemungkinan terjadi sebelum responden mengikuti pendidikan dokter gigi. Meskipun demikian, hal ini dapat menggambarkan bahwa responden sering melakukan kunjungan ke dokter gigi walaupun temuan dalam penelitian ini menunjukkan bahwa mereka umumnya melakukan pencabutan gigi.

Hasil ini berbeda dengan penelitian yang dilakukan oleh Erguven dan Kalyoncuoglu ${ }^{6}$ terhadap 205 mahasiswa kedokteran gigi di Ankara, Turki. Penelitian tersebut menunjukkan prevalensi kehilangan gigi yang lebih rendah dibandingkan dengan penelitian ini, yaitu sebesar $29,3 \%$. Sebanyak 60 responden mengalami kehilangan gigi, sedangkan 145 orang $(70,7 \%)$ lainnya tidak menderita kehilangan gigi. Demikian halnya dengan penelitian AlMousawi et $\mathrm{al}^{7}$ terhadap 288 mahasiswa kedokteran gigi di Irak yang melaporkan prevalensi gigi yang telah dicabut sebesar $31,7 \%$ atau sebanyak 91 orang.

Dilihat dari distribusi kehilangan gigi menurut jenis kelamin, perempuan lebih banyak mengalami kehilangan gigi daripada laki-laki. Hal ini dapat disebabkan oleh jumlah responden berjenis kelamin perempuan yang lebih banyak dibandingkan laki-laki yaitu sebanyak 110 orang $(70,5 \%)$ vs 46 orang $(29,5 \%)$. Hasil ini sejalan dengan penelitian Erguven dan Kalyoncuoglu ${ }^{6}$ yang mendapatkan responden mahasiswa kedokteran gigi berjenis kelamin perempuan lebih banyak yaitu 143 orang atau $69,8 \%$ dibandingkan laki-laki yang berjumlah 62 orang $(30,2 \%)$, akan tetapi pada penelitian tersebut tidak disebutkan jumlah kehilangan gigi berdasarkan jenis kelamin.

Kehilangan gigi dapat terjadi pada satu atau beberapa gigi. Pada penelitian ini terdapat responden yang mengalami kehilangan tujuh (7) gigi, sedangkan kehilangan dua (2) gigi paling banyak dialami oleh mahasiswa tahap profesi PSPDG FK Unsrat yaitu sebanyak 40 orang. Keadaaan hilangnya gigi mencerminkan riwayat penyakit gigi dan mulut pasien. Salah satu indikator penting yang menunjukkan status kesehatan mulut yaitu jumlah gigi. ${ }^{4}$ Penurunan jumlah gigi asli dikaitkan dengan ketidakmampuan mengunyah dan berdampak pada kemampuan kognitif. Peningkatan jumlah kehilangan gigi juga dapat memperburuk depresi dan tingkat kecemasan seseorang. ${ }^{6}$

Hilangnya gigi dapat disebabkan oleh beberapa faktor di antaranya karies dan penyakit periodontal. Kehilangan gigi akibat karies atau periodontitis tetap menjadi masalah kesehatan masyarakat termasuk mahasiswa tahap profesi dokter gigi meskipun kemajuan teknis, farmakologis dan bedah dalam bidang kedokteran gigi. ${ }^{6}$ Hasil penelitian ini menunjukkan karies merupakan penyebab kehilangan gigi paling tinggi yaitu sebanyak 144 gigi atau $60 \%$. Penelitian oleh Al-Mousawi et $\mathrm{al}^{7}$ menunjukkan mahasiswa kedokteran gigi di Irak yang mengalami karies gigi sebanyak 135 orang atau $48 \%$. Karies gigi adalah penyakit akibat bakteri spesifik terutama Streptococcus mutans yang melekat pada gigi dan memetabolismir gula untuk menghasilkan asam, yang seiring berjalannya waktu akan mendemineralisasi struktur gigi. ${ }^{8}$

Penyebab utama kehilangan gigi selain karies ialah penyakit periodontal namun dalam penelitian ini tidak terdapat kehilangan gigi yang disebabkan oleh penyakit periodontal. Penyakit periodontal adalah penyakit yang mengenai jaringan pendukung gigi, yaitu gingiva/gusi serta jaringan periodontal, yaitu jaringan yang menghu- 
bungkan antara gigi dan tulang penyangga gigi yaitu tulang alveolar. ${ }^{9}$ Mahasiswa kedokteran gigi merupakan perwakilan dari kelas individu yang berpendidikan, berpengaruh, dan diharapkan fasih dengan masalah kesehatan gigi dan mulut. Mereka harus memiliki motivasi dan pengetahuan yang baik untuk memberikan sikap yang tepat dalam masyarakat. ${ }^{10}$

Setelah kehilangan gigi, resorpsi residual ridge akan berjalan secara signifykan yang mengarah pada pengurangan ketinggian tulang alveolar. Selain itu, ketebalan otot maseter ditemukan menurun pada pasien edentulous yang mengurangi kekuatan gigitan. ${ }^{4}$ Seseorang yang memiliki kehilangan gigi terutama gigi posterior akan terganggu fungsi pengunyahan yang membuatnya merasa sulit dalam mengonsumsi makanan. ${ }^{11}$ Hal ini memiliki dampak negatif pada diet dan pemilihan makanan. ${ }^{4}$

Kehilangan gigi yang dibiarkan juga akan berdampak secara fisik maupun psikis yang menyebabkan keterbatasan saat berbicara, serta memengaruhi sendi temporomandibular hingga penampilan estetik. ${ }^{11}$ Oleh karena kehilangan gigi dapat memengaruhi kualitas hidup, ${ }^{11}$ maka gigi yang hilang perlu digantikan dengan gigi tiruan. Namun dalam penelitian ini, dari 240 gigi yang hilang, hanya 38 gigi yang digantikan dengan gigi tiruan, sedangkan 202 gigi lainnya tidak dibuatkan gigi tiruan. Hal ini tentunya tidak mencerminkan pengetahuan kesehatan gigi dan mulut yang baik dari mahasiswa tahap profesi dokter gigi. Mahasiswa profesi dokter gigi menawarkan berbagai layanan kesehatan kepada pasien yang menderita masalah gigi dan mulut termasuk pembuatan gigi tiruan. Akan tetapi sebagai pemberi layanan kesehatan gigi dan mulut di masa depan, mereka justru membiarkan gigi yang hilang tidak digantikan dengan gigi tiruan dengan berbagai pertimbangan atau alasan yang dapat dilihat pada Tabel 4.

Selain alasan untuk keperluan perawatan ortodonsi dan gigi impaksi yang memang tidak memerlukan penggantian gigi, sebanyak 46 gigi tidak dibuatkan gigi tiruan karena belum sempat atau tidak ada waktu. Mahasiswa tahap profesi dokter gigi diharuskan menyelesaikan semua requirement kasus dalam waktu dua tahun di bawah bimbingan dosen pembimbing klinik. Hal ini kemungkinan dapat menyebabkan mahasiswa tahap profesi dokter gigi tidak memiliki waktu untuk memikirkan kesehatannya sendiri termasuk menggantikan gigi yang hilang dengan gigi tiruan. Sebanyak empat (4) gigi tidak dibuatkan gigi tiruan dengan alasan masih ragu atau takut untuk memakai gigi tiruan. Hal ini kemungkinan karena mereka mengetahui bahwa pemakai gigi tiruan hanya memiliki sekitar seperlima hingga seperempat kekuatan gigitan dan kekuatan pengunyahan gigi asli. Selanjutnya, individu yang menggunakan gigi tiruan lengkap membutuhkan kekuatan mengunyah tujuh kali lebih besar daripada gigi asli untuk dapat memotong makanan menjadi setengah dari ukuran aslinya. Hal ini menyebabkan individu yang memakai gigi tiruan lengkap mengalami kesulitan mengunyah makanan keras. ${ }^{4}$

\section{SIMPULAN}

Prevalensi kehilangan gigi pada mahasiswa tahap profesi PSPDG FK Unsrat didapatkan sebesar $66 \%$. Jenis kelamin perempuan lebih banyak mengalami kehilangan gigi daripada laki-laki. Karies merupakan penyebab kehilangan gigi paling tinggi. Sebagian besar gigi yang hilang tidak dibuatkan gigi tiruan dengan berbagai alasan.

Diharapkan mahasiswa tahap profesi dokter gigi sebagai pemberi layanan masalah kesehatan gigi dan mulut kepada masyarakat di masa depan harus memiliki motivasi dan pengetahuan yang baik untuk memberikan sikap yang tepat dalam masyarakat tentang kesehatan gigi dan mulut.

\section{Konflik Kepentingan}

Penulis menyatakan tidak terdapat konflik kepentingan dalam penelitian ini.

\section{DAFTAR PUSTAKA}

1. Al-Rafee MA. The epidemiology of edentulism and the associated factors: A literature review. J Family Med Prim Care. 2020;9(4):1841-3. 
Doi: 10.4103/jfmpc.jfmpc_1181_19

2. Anshary MF, Fauzan M, Cholil, Arya IW. Gambaran pola kehilangan gigi sebagian pada masyarakat desa Guntung Ujung Kabupaten Banjar. J Dentino Ked Gigi. 2014;2(2):138-43.

3. Dosumu OO, Oguninde JT, Bamigboye SA. Knowledge of consequences of missing teeth in patients attending prosthetic clinic in u.C.h. Ibadan. Ann Ib Postgrad Med. 2014;12(1):42-8. PMID: 25332700; PMCID: PMC4201933.

4. Emami E, de Souza RF, Kabawat M, Feine JS. The impact of edentulism on oral and general health. Int J Dent. 2013: 2013;2013:498305. Available from: http://dx.doi.org/10.1155/2013/498305

5. Program Studi Pendidikan Dokter Gigi Fakultas Kedokteran Universitas Sam Ratulangi. Portal satu data.

6. Erguven SS, Kalyoncuoglu UT. Effect of tooth loss on social appearance anxiety and oral health related quality of life among dental students. J Basic Clin Health Sci 2021;3:165-70.

7. Al-Mousawi A. Alali BA, Al-Mousawi Z. The prevalence of dental caries among students of Dentistry Colleges in Holy Kerbala Governorate/Iraq in 2017. J Contemp Med Sci 2019;5(3):154-9.

8. Rathee M, Sapra A. Dental Caries. In: StatPearls [Internet]. Treasure Island (FL): StatPearls Publishing; 2021 JanAvailable from: https://www.ncbi. nlm.nih.gov/books/NBK551699/

9. Siagian KV. Kehilangan sebagian gigi pada rongga mulut. e-CliniC. 2016;4(1).

10. Sood M, Kumar A, Kumar N. Evaluation of periodontal disease in dental students. Contemp Clin Dent. 2010;1(1): 14-6. Doi:10.4103/0976-237X.62513

11. Rizkillah MN, Isnaeni RS, Fadilah RPN. Pengaruh kehilangan gigi posterior terhadap kualitas hidup pada kelompok usia 45-65 tahun. Padjadjaran J Dent Res Student. 2019;3(1):7-12. 